\title{
Hubungan Anemia Pada Ibu Hamil Terhadap Kejadian Stunting di RS Marthen Indey Jayapura Tahun 2018-2019
}

\author{
Gevo T. J. Salakory, ${ }^{*}$ Ida B. E. U. Wija \\ Departemen Ilmu Kesehatan Anak Fakultas Kedokteran Universitas Kristen Indonesia
}

\begin{abstract}
Abstrak
Penelitian ini dilakukan untuk mengetahui hubungan antara anemia yang terjadi pada ibu hamil dengan tingkat kejadian stunting di Rumah Sakit Marthen Indey Jayapura dengan Insuline-like Growth Factors (IGF) sebagai salah satu faktor penyebab. Menggunakan metode deskriptif analitik dengan desain studi retrospective dan didapatkan 30 sampel dari total 80 populasi ibu hamil yang mengalami anemia. Didapatkan $15(50 \%)$ sampel yang memiliki panjang badan bayi $36-40 \mathrm{~cm}, 13(43,3 \%)$ sampel yang memiliki panjang badan bayi $41-45 \mathrm{~cm}$ dan $2(6,7 \%)$ sampel yang memiliki panjang badan bayi $>45 \mathrm{~cm}$ dengan nilai $\mathrm{p}=0,004(\mathrm{p}<0,05)$ dari hasil uji statistik chi square Ditemukan hubungan antara anemia pada ibu hamil terhadap tingkat kejadian stunting di Rumah Sakit Marthen Indey Jayapura.
\end{abstract}

Kata Kunci: Anemia pada Ibu Hamil, Insuline-like Growth Factors, Stunting

\section{The Relationship of Anemia in Pregnant Women to Stunting at Marthen Indey Hospital, Jayapura, 2018-2019}

\begin{abstract}
This study was conducted to determine wheter there is a relationship between anemia that occurs in pregnant women and the incidence of stunting at Marthen Indey Hospital, Jayapura with Insuline-like Growth Factors (IGF) as a contributing factor. The study was conducted using a descriptive analytical method with a retrospective study design and obtained 30 samples from a total of 80 population of pregnant women with anemia. The result showed that $15(50 \%)$ sample had a baby body length $36-40 \mathrm{~cm}, 13(43,3 \%)$ sample had a baby length $41-45 \mathrm{~cm}$ and $2(6,7 \%)$ samplea had a baby body length $>45 \mathrm{~cm}$ with $\mathrm{p}$ value $=0,004(\mathrm{p}<0,05)$ from the result of the chi square statistical test. From the analysis, it was found that there was a relationship between anemia in pregnant women and the incidence of stunting at Marhen Indey Hospital, Jayapura.
\end{abstract}

Keywords: Anemia in Pregnant Women, Insuline-like Growth Factors, Stunting

*GTJS: Penulis Koresponden, E-mail: gevosalakory2016@gmail.com 


\section{Pendahuluan}

Anemia merupakan suatu kondisi dimana berkurangnya kadar hemoglobin $(\mathrm{Hb})$ dari normal. Menurut World Health Organization (WHO) ibu hamil dikatakan menderita anemia jika kadar hemoglobin (Hb) dalam darah $\leq 11 \mathrm{~g} / \mathrm{dL}$. Banyak faktor yang dapat mempengaruhi terjadinya anemia namun lebih dari 50\% kasus yang banyak terjadi anemia disebabkan secara langsung karena berkurangnya masukan zat gizi besi yang biasa dikenal dengan anemia defisiensi besi. Anemia defisiensi besi terjadi karena kebutuhan tubuh yang meningkat, salah satunya karena peningkatan kebutuhan zat besi sewaktu hamil. ${ }^{1}$

Saat hamil, kebutuhan zat besi pada ibu hamil semakin meningkat seiring bertambahnya usia kehamilan. Peningkatan volume darah dimulai sejak trimester I sebanyak $15 \%$ dibandingkan dengan keadaan sebelum hamil. Kemudian akan terjadi peningkatan yang sangat pesat pada trimester II. Pada setiap $1000 \mathrm{mg}$ zat besi yang dibutuhkan saat kehamilan, sekitar $300 \mathrm{mg}$ zat besi akan dikirim secara aktif ke janin dan plasenta. ${ }^{2}$ Secara umum terdapat tiga penyebab anemia defisiensi besi pada ibu hamil yaitu kecenderungan rendahnya cadangan zat besi (Fe) pada wanita saat menstruasi dan persalinan sebelumnya, kekurangan asupan zat besi dari makanan yang dikonsumsi dan pola makan pada ibu hamil terganggu yang dikarenakan mual yang dirasakan selama kehamilan. ${ }^{3}$

Stunting merupakan kondisi dimana balita dengan status gizi yang jika diukur panjang atau tinggi badan menurut umur balita tersebut nilai z-scorenya $<-2 \mathrm{SD}$ berdasarkan standar baku World Health Organization-Multicentre Growth Reference Study (WHO-MGRS) tahun 2005. Stunting menggambarkan masalah gizi yang serius dan dipengaruhi dari kondisi ibu/calon ibu, masa janin dan masa balita termasuk juga dengan penyakit yang diderita selama masa balita. $^{4}$

Salah satu faktor penyebab stunting yang memberikan dampak besar pada tumbuh kembang anak yaitu Insuline-like Growth Factors (IGF) yang merupakan growth promoting factor dalam proses tumbuh kembang anak dan juga sebagai mediator untuk Growth Hormone (GH) yang berfungsi untuk meningkatkan pertumbuhan linear anak. ${ }^{5}$

Defisiensi besi dapat mempengaruhi pertumbuhan linier dikarenakan zat besi merupakan nutrient tipe 2 yang dibutuhkan dalam proses tumbuh kembang anak sebagai bahan pokok dalam pembentukan jaringan. Zat besi juga dapat meningkatkan Insuline-like Growth Factor (IGF) yang akan mempercepat pertumbuhan tulang. Itulah mengapa jika ibu hamil mengalami anemia defisiensi besi yang mengakibatkan konsentrasi IGF dalam berkurang dapat mengakibatkan transport nutrient yang didapatkan janin dari ibu tidak maksimal maka pertumbuhan dan perkembangan janin pun menjadi tidak maksimal. Dalam hal ini IGF berfungsi untuk mengantarkan hormon pertumbuhan yang berperan dalam suatu growth promoting factor. ${ }^{6,7}$

Tujuan penelitian ini yaitu untuk mengetahui hubungan antara anemia pada ibu hamil dengan kejadian stunting di RS Marthen Indey Jayapura dengan ibu hamil yang menderita anemia sebagai variabel bebas.

\section{Bahan dan Cara}

Pada penelitian ini menggunakan metode deskriptif analitik dengan desain studi retrospective dan teknik simple random sampling dimana data diambil dari seluruh pasien anak yang terdiagnosis stunting dan ibu hamil yang menderita anemia.

Pengambilan data dilakukan di bagian rekam medik Rumah Sakit Marthen Indey 
Jayapura. Selanjutnya data rekam medik yang sesuai dengan variabel penelitian akan dicatat. Semua data yang telah diperoleh disaring sesuai dengan kriteria inklusi dan kriteria eksklusi yang telah ditetapkan, kemudian diolah menggunakan program komputer. Data dianalisis secara multivariat.

\section{Hasil}

Data yang diperoleh dari hasil penelitian didapatkan 15 pasien $(50,0 \%)$ masuk ke dalam kategori 36 - $40 \mathrm{~cm}$. Sebanyak 13 pasien $(43,3 \%)$ masuk ke dalam kategori $41-45 \mathrm{~cm}$ dimana sebagian besar bayi memiliki panjang badan yang kurang dari 45 cm (Tabel 1).

\begin{tabular}{ccc}
\multicolumn{2}{c}{$\begin{array}{c}\text { Tabel 1. Distribusi Profil Pasien Anemia } \\
\text { pada Ibu Hamil berdasarkan Panjang } \\
\text { Badan Bayi }\end{array}$} \\
\hline \multicolumn{3}{c}{ Panjang Badan } \\
Bayi & $\begin{array}{c}\text { Frekuensi } \\
\text { (pasien) }\end{array}$ & Persentase (\%) \\
\hline $36-40 \mathrm{~cm}$ & 15 & 50,0 \\
$41-45 \mathrm{~cm}$ & 13 & 43,3 \\
$46-50 \mathrm{~cm}$ & 2 & 6,7 \\
Total & $\mathbf{3 0}$ & $\mathbf{1 0 0}$ \\
\hline
\end{tabular}

Data kadar hemoglobin yang diperoleh dari hasil penelitian menunjukkan 5 pasien $(16,7 \%)$ masuk ke dalam kategori 5,1 - 6 gr $\%, 8$ pasien $(26,7 \%)$ masuk ke dalam kategori $6,1-7$ gr \%, 7 pasien $(23,3 \%)$ masuk ke dalam kategori $7,1-8$ gr $\%$ dan $8,1-9$ gr \%, 2 pasien $(6,7 \%)$ masuk dalam kategori 9,1 - 10 gr \% dan 1 pasien $(3,3 \%)$ masuk ke dalam kategori 10,1 - 11 gr \% (Tabel 2).

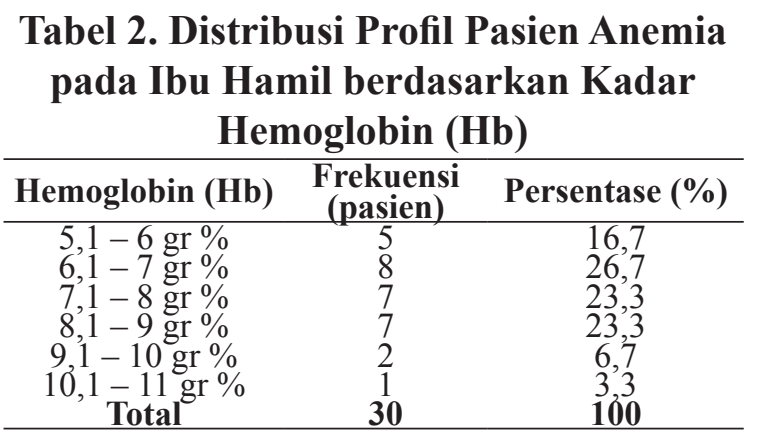

Hasil penelitian menunjukkan ada keterkaitan antara kadar hemoglobin pada ibu hamil dengan panjang badan bayi (Tabel 3). Kadar hemoglobin rendah pada ibu hamil memiliki bayi dengan panjang badan di bawah $45 \mathrm{~cm}$. Sebanyak 15 pasien (50\%) yang memiliki tingkat kejadian panjang badan bayi 36 - $40 \mathrm{~cm}$ dimana kadar hemoglobin pada ibu saat mengandung 5,1 - 9 gr \%, 13 pasien (43,3\%) yang memiliki tingkat kejadian panjang badan bayi $41-45$ $\mathrm{cm}$ dimana kadar hemoglobin pada ibu saat mengandung $5,1-10$ gr\%, 2 pasien $(6,7 \%)$ yang memiliki tingkat kejadian panjang badan bayi 46 - $50 \mathrm{~cm}$ dimana kadar hemoglobin pada ibu saat mengandung 9,1 $-11 \mathrm{gr} \%$.

Tabel 3. Hubungan Kadar Hemoglobin pada Ibu Hamil dan Panjang Badan Bayi

\begin{tabular}{|c|c|c|c|c|c|c|c|c|c|}
\hline \multicolumn{10}{|c|}{ Kadar Hemoglobin pada Ibu Hamil } \\
\hline \multirow{5}{*}{$\begin{array}{c}\text { Panjang } \\
\text { Badan Bayi }\end{array}$} & & $\begin{array}{l}5,1-6 \\
\text { gr \% }\end{array}$ & $\begin{array}{l}6,1-7 \\
\text { gr \% }\end{array}$ & $\begin{array}{c}7,1-8 \\
\text { gr \% }\end{array}$ & $\begin{array}{c}8,1-9 \mathrm{gr} \\
\%\end{array}$ & $\begin{array}{c}9,1-10 \\
\text { gr \% }\end{array}$ & $\begin{array}{c}10,1-11 \\
\text { gr } \%\end{array}$ & Total & \multirow[t]{4}{*}{ Nilai p } \\
\hline & $36-40 \mathrm{~cm}$ & $\begin{array}{c}3 \\
(10 \%)\end{array}$ & $\begin{array}{c}6 \\
(20 \%)\end{array}$ & $\begin{array}{c}2 \\
(6,7 \%)\end{array}$ & $\begin{array}{c}4 \\
(13,3 \%)\end{array}$ & $\begin{array}{c}0 \\
(0 \%)\end{array}$ & $\begin{array}{c}0 \\
(0 \%)\end{array}$ & $\begin{array}{c}15 \\
(50 \%)\end{array}$ & \\
\hline & $41-45 \mathrm{~cm}$ & 2 & 2 & 5 & 3 & 1 & 0 & 13 & \\
\hline & & $(6,7 \%)$ & $(6,7 \%)$ & $(16,7 \%)$ & $(10 \%)$ & $(3,3 \%)$ & $(0 \%)$ & $(43,3 \%)$ & \\
\hline & $46-50 \mathrm{~cm}$ & 0 & 0 & 0 & 0 & 1 & 1 & 2 & 0,004 \\
\hline \multicolumn{2}{|c|}{ Total } & $\begin{array}{c}(0 \%) \\
5 \\
(16,7 \%)\end{array}$ & $\begin{array}{c}(0 \%) \\
8 \\
26,7 \%)\end{array}$ & $\begin{array}{c}(0 \%) \\
7 \\
(23,3 \%)\end{array}$ & $\begin{array}{c}(0 \%) \\
7 \\
(23,3 \%)\end{array}$ & $\begin{array}{c}(3,3 \%) \\
2 \\
(6,7 \%)\end{array}$ & $\begin{array}{c}(3,3 \%) \\
1 \\
(3,3 \%)\end{array}$ & $\begin{array}{c}(0,7 \%) \\
30 \\
(100 \%)\end{array}$ & \\
\hline
\end{tabular}




\section{Diskusi}

Hasil penelitian menunjukkan bahwa bayi-bayi tersebut memiliki panjang badan $<-2$ SD yang merupakan standar baku dari WHO-MGRS untuk menentukan kondisi stunting pada bayi. ${ }^{8,9}$ Selain itu, kadar hemoglobin yang rendah memberikan dampak pada pertumbuhan linier anak dikarenakan hemoglobin merupakan nutrien tipe 2 yang berguna dalam proses pembentukan jaringan dan pertumbuhan tulang. ${ }^{6}$ Oleh karena hemeglobin memerlukan besi pada proses biosintesisnya, maka asupan besi merupakan kebutuhan yang penting bagi ibu hamil. Kebutuhan zat besi pada ibu hamil semakin meningkat seiring bertambahnya usia kehamilan. ${ }^{2,10}$

\section{Kesimpulan}

Penelitian menunjukkan ada hubungan yang signifkan antara tingkat kejadian stunting di Rumah Sakit Marthen Indey Jayapura dengan ibu hamil yang menderita anemia.

\section{Daftar Pustaka}

1. Kementrian Kesehatan Republik Indonesia. Badan Penelitian dan Pengembangan Kesehatan. J Kesehat Reproduksi. Jakarta. 2016.

2. Cunningham FG, Leveno KJ, Bloom SL, Hauth JC, Rouse DJ, Spong CY. Obstetri Williams. 23 ed. Yovita, Salim N, Setia R, Nalurita, Muliawan E, Rifky, et al., editor. Jakarta: EGC;2012. 16-31

3. Tasya OHIM. kajian asupan protein dan asam folat pada ibu hamil anemia di wilayah lokus stunting di Kabupaten Kulon Progo. Poltekkesjogja. Yogyakarta. 2019.

4. Infodatin. Pusat Data dan Informasi Kementrian Kesehatan RI. Situasi Balita Pendek. Jakarta. 2016.

5. Wija IBEU, Hilman LP. Anemia defisiensi besi pada ibu hamil dan stunting. Maj Kedokt UKI. 2018.34(3).144-9

6. Dewi EK, Nindya TS. Hubungan tingkat kecukupan zat besi dan seng dengan kejadian stunting pada balita 6-23 bulan. E-journal Universitas Airlangga. Surabaya. 2017.

7. Nasution YF, Lipoeto NI, Yulizawati Y. Hubungan kadar insuline-like growth factor 1 serum maternal dengan berat badan dan panjang badan bayi baru lahir pada ibu hamil KEK. Maj Kedokt Andalas.2019;42(35).19-26

8. Infodatin. Pusat Data dan Informasi Kementrian Kesehatan RI. Situasi Balita Pendek. Jakarta. 2016.

9. Kementrian Kesehatan RI. Direktorat Jenderal Bina Gizi dan Kesehatan Ibu dan Anak. Keputusan Menteri Kesehatan Republik Indonesia Nomor: 1995/MENKES/SK/XII/2010 Tentang Standar Antropometri Penilaian Status Gizi Anak. Jakarta. 2011.

10. Susiloningtyas I. Pemberian Zat Besi (Fe) Dalam Kehamilan. Majalah Ilmiah Sultan Agung. 2012:50(128).2-21 